\title{
RESSONÂNCIAS DE NIETZSCHE EM FOUCAULT: O ENCONTRO CRIATIVO DA FLECHA DO PENSAMENTO
}

\author{
Aline Ribeiro Nascimento ${ }^{1}$ \\ Universidade do Estado do Rio de Janeiro (UERJ) \\ (D) https://orcid.org/0000-0003-3760-7466
}

\section{RESUMO:}

$\mathrm{O}$ presente artigo é divido em duas partes. Na primeira, servindo-se da imagem da flecha, tal como Nietzsche a apresenta ao longo de várias obras, buscará formular o conceito de flecha do pensamento. Na segunda, mostrará a ressonância desse conceito nos escritos de Foucault, objetivando apresentar a presença de Nietzsche ao longo de toda a trajetória de seu pensamento.

PALAVRAS-CHAVE: Flecha; Nietzsche; Foucault; Arqueologia; Genealogia.

\section{RESONANCES OF NIETZSCHE IN FOUCAULT: THE CREATIVE ENCOUNTER OF ARROW OF THOUGHT}

\begin{abstract}
:
This article is divided into two parts. In the first, by using the image of the arrow, as Nietzsche presents along several works, will seek to formulate the concept of arrow of thought. In the second, shows the resonance of this concept in the writings of Foucault, aiming to show the presence of Nietzsche throughout the trajectory of his thought.
\end{abstract}

KEYWORD: Arrow; Nietzsche; Foucault; Archeology; Genealogy.

\footnotetext{
${ }^{1}$ Pós-doutoranda em Psicologia Social pela Universidade do Estado do Rio de Janeiro (UERJ), Rio de Janeiro - Brasil, bolsista do CNPq, Doutora em Memória Social pela Universidade Federal do Estado do Rio de Janeiro (UNIRIO), Rio de Janeiro - Brasil, Mestre em Psicologia pela Universidade Federal Fluminense (UFF), Rio de Janeiro Brasil. E-mail: alinenascimento_prof@yahoo.com.br
} 
Introdução

A natureza envia o filósofo à humanidade como uma flecha; ela não mira, mas espera que a flecha fique presa em algum lugar (NIETZSCHE, 2003b, § 7, p.201)

O presente artigo tem por base a definição do que chamamos de "pensamento flecha" a partir de alguns escritos de Nietzsche. Para tanto, foi necessário recorrer a obras de Nietzsche $(1992,1994,1995,2000 b, 2003 b)$ nas quais a imagem da flecha estivesse presente e, além disso, ver se essa escolha nos possibilitava uma compreensão global da sua proposta filosófica. Num segundo momento, buscaremos mostrar a ressonância desta "qualidade" de pensamento na obra de Foucault, posto que, conforme podemos observar, já nessa citação de abertura, um pensamento-flecha é uma ocasião em que uma força, tal como Nietzsche, quando atinge o leitor de sua obra, o força a pensar de outra maneira, e tal processo só é possível quando finca-se em um outro pensador, em outro tempo. Diante disso, quando essa flecha é experienciada no próprio corpo desse outro pensador, este se transforma em arqueiro e, dessa maneira, mantém a flecha intempestiva ${ }^{2}$, podendo, assim, ser lançada em outras direções, como assinala Deleuze, referindo-se a Foucault (1992, p.146-147).

A escolha desse ponto de partida não foi aleatória ou estilística, pois levou em conta o lugar de destaque que Nietzsche confere às imagens ligando-as conceitos, afinal são pensadas, por ele, como "grupo de sensações" ou "bloco de sensações", dizendo, ainda que "palavras são sinais sonoros para conceitos; mas conceitos são sinais-imagens, mais ou menos determinadas, para sensações recorrentes e associadas, para grupo de sensações" (NIETZSCHE, 1992,§ 268, p. 182). Além disso, uma imagem como a que escolhemos, só se torna um signo de comunicação, quando não simplesmente é usada de forma repetida para que nos compreendamos, mas quando é utilizada para comunicar uma mesma espécie de vivências interiores (1992b, §268, p.182).

\section{Nietzsche e a flecha, Nietzsche como flecha...}

Ao percorrernos a imagem da flecha nos escritos de Nietzsche, pudemos conferir a ela cinco sentidos e, ao final desse processo inicial da pesquisa, acabamos percebendo que ela nos proporcionava a ressonância

\footnotetext{
2 Aqui nos remetemos ao caráter intempestivo das obras de Nietzsche, entendendo por intempestividade como estar "contra o tempo, e com isso, no tempo, esperando, com isso, estar a favor de um tempo vindouro" (NIETZSCHE, 2003a, p.7)
}

Ressonâncias de Nietzsche em Foucault: o encontro criativo da flecha do pensamento - Aline Ribeiro Nascimento 
perfeita com os escritos de Foucault, nos assinalando uma vivência interior comum entre Foucault e Nietzsche. Essa vivência interior comum pode ser ilustrada através de Zaratustra (p. 57), quando em seu discurso sobre "as mil metas e uma só meta" nos adverte: " dizer a verdade [é] saber manejar bem o arco e a flecha" ${ }^{3}$ e a partir dela, pudemos sintetizar cinco sentidos para o que seria um pensamento-flecha ou como atirar bem com flechas:

1- tem um alvo no presente e esse alvo emerge do diagnóstico das forças que dão contorno às formas de pensamento, mas para delas se deslocar ${ }^{4}$, o que, em Foucault foi chamado de ontologia histórica de nós mesmos, que não se refere a uma analítica da verdade, mas uma ontologia da atualidade, uma problematização daquilo que nos tornamos, ou seja, "a crítica do que somos é a um e ao mesmo tempo análise histórica dos limites que nos são impostos e um experimento com a possibilidade de ir além deles" (DREYFYS E RABINOW, 1984, p.50).

2- que implica numa atitude capaz de sustentar a tensão do arco ${ }^{5}$ para que esse alvo seja atingido, mostrando que o lançamento da flecha é tarefa do homens fortes, isto é, aqueles que sabem fazer a corda de seu arco vibrar ${ }^{6}$. De modo que a tarefa dstes consiste "em não afrouxar a tensão do $\operatorname{arco}^{17}$, o que, em Foucault está relacionado a construção de um ethos, de uma atitude, de um corpo, capaz de sustentar problematizações e, a partir delas,

${ }^{3}$ Tal manejo fica evidente em todos os seus escritos, mas a título de exemplo podemos dizer que não é sem motivos que, no Crepúsculo dos Ídolos, Nietzsche, logo após o prólogo, apresenta 44 breves aforismos numa seção que intitula como "Máximas e flechas", afirmando, posteriormente, no Ecce Homo, que "aquilo que no título se chama ídolo é simplesmente o que até agora se denominou verdade. Crepúsculo dos Ídolos - leia-se: adeus à velha verdade" (1995, p.99).

${ }^{4}$ Sustentar a tensão implica em força para criar pensamentos/conceitos intempestivos. Podemos afirmar que todas as obras de Nietzsche tem essa característica, isto é, tanto a forma como escreve, quanto os alvos que escolhe atacar ilustram bem a potência disruptiva de sua flecha. No Ecce Homo, por exemplo, quando discorre acerca da intempestividade de seus escritos, dirá que na Segunda Consideração Intempestiva: da utilidade e desvantagem da história para a vida, esse exercício do espírito o tornou capaz de diagnosticar o presente (século XIX) definindo esse escrito como aquele no qual "o sentido histórico de que tanto se orgulha este século foi pela primeira vez reconhecido como doença, como sinal de declínio" (1995,p.67).

5 Alusão a luta contra o platonismo e o cristianismo, tal como aparece no prefácio de Além do Bem e do Mal : "Mas a luta contra Platão, ou, para dizê-lo de modo mais simples e para o "povo", a luta contra a pressão cristã-eclesiástica de milênios — pois o cristianismo é o platonismo para o "povo" - produzia na Europa uma magnífica tensão de espírito como até então não havia na terra: com um arco assim teso pode-se agora mirar nos alvos mais distantes". (1992, Prólogo, p.8).

${ }^{6}$ Alusão a uma passagem ao prólogo $\mathrm{V}$ do Zaratustra quando, ao diz aos últimos homens: “Ai de nós! Aproxima-se o tempo em que o homem não mais arremessará a flecha do seu anseio para além do homem e a corda de seu arco terá desaprendido a vibrar (...) já é tempo de o homem estabelecer sua meta. Já é tempo de o homem plantar a semente da sua mais alta esperança",

${ }^{7}$ Cf. NIETZSCHE, 1992, p.109.

Ressonâncias de Nietzsche em Foucault: o encontro criativo da flecha do pensamento - Aline Ribeiro Nascimento 
criar estratégias e táticas de intervenção no socius, bem como encontrar maneiras mais libertárias de governar a si mesmo, tal como propõe em seus últimos escritos ${ }^{8}$,

3- que, munidos da força, podem atingir, também, alvos distantes, posto que quanto mais teso o arco, mais longe vai a flecha e, com isso, podem encontrar um pensador do futuro que a recolhe e que pode lançá-la em novas direções, o que, conforme veremos, foi o exercício feito por Foucault, ao longo de todos os seus escritos, a partir da flecha - Nietzsche. Isto é, Foucault, leitor de Nietzsche, se tornou alvo de suas flechas e mais do que leitor, perpetuador de sua vibratibilidade;

4- que todo esse processo envolve um aprendizado de que o tiro certeiro é aquele no qual não se faz um grande barulho ${ }^{9}$, pois o ato de criar novos valores não deriva dos grandes acontecimentos, mas da percepção de pequenos acontecimentos cuja força sutil e precisa só é percebida por quem tem sensibilidade na audição, aquele ouvinte de orelhas pequenas ${ }^{10}$, que pode perceber que "as palavras silenciosas são as que carregam maior tempestade"(NIETZSCHE, 1995, p. 19) e assim caminham na contramão do modo como comumente se escuta e se desenha a história. O que em Foucault se caracterizou tanto no exercício arqueológico, quanto no que ele nomeia como genealogia do poder, bem como no que mais tarde define como genealogia da ética;

5- coragem e firmeza na sustentação da tensão e da ausência de ruídos quando a flecha sai do arco, posto que ela só abrirá novos caminhos se o arqueiro não tremer as mãos no lançamento, ou seja, quando é capaz de fazer da vibração da corda no arco, sem trepidação, a afinação entre vida e pensamento, estando inteiro num exercício ético que espiritualiza o tiro, exercício que tanto Nietzsche quanto Foucault fizeram ao longo de sua vida, tendo em vista que conseguiram fazer do pensamento a própria ferramenta do pensamento; ou antes, a de fazer do pensamento um corpo que se

\footnotetext{
${ }^{8}$ Dai afirmar, no texto $O$ Sujeito e o Poder, um de seus últimos trabalhos, "que problema político, ético, social e filosófico de nossos dias não consiste em tentar liberar o indivíduo do Estado nem das instituições do Estado, porém nos liberarmos tanto do Estado quanto do tipo de individualização que a ele se liga. Temos que promover novas formas de subjetividade através da recusa deste tipo de individualidade que nos foi imposto há vários séculos (FOUCAULT, 2014,p. 128).

9 Alusão à passagem uma passagem do Zaratustra intitulada "De grandes acontecimentos", quando diz: "Liberdade é o vosso grito preferido; mas eu desaprendi a ter fé nos "grandes acontecimentos" desde que à sua volta haja demasiado barulho (...) Os maiores acontecimentos - não são as nossas horas mais barulhentas, mas as mais silenciosas. Não em torno de novos barulhos: em torno dos inventores de novos valores, gira o mundo; gira inaudível"(1994, p. 143).

10 Essa temática das orelhas está presente nas passagens do Zaratustra chamadas, respectivamente, Da redenção" e "O Despertar", mas também percorre vários escritos de Nietzsche, como o Ecce Homo, na seção Por que escrevo livros tão bons, aforismos de Humano demasiado Humano ( §217), A Gaia Ciência (§346, §381), só para citar alguns.
}

Ressonâncias de Nietzsche em Foucault: o encontro criativo da flecha do pensamento - Aline Ribeiro Nascimento 
conquista por meio de técnicas capazes de nos colocar diante de nós mesmos. (NASCIMENTO, A.R e RODRIGUES, H.C.B, 2014)

Podemos observar, ainda que de forma breve, que essas dimensões de análise, esses cinco sentidos conferidos ao pensamento-flecha nietzschiano, estavam também presentes nos escritos de Foucault. É importante assinalar que em alguns momentos essa presença era literal, isto é, Foucault se utilizava de citações de obras de Nietzsche para amplificar alguma discussão ( falamos aqui da fase arqueológica) em outros, dando a Nietzsche novas formulações derivadas de seus conceitos (fase genealógica) ou ainda criando conceitos novos, sem mencionar Nietzsche, mas sempre nos colocando diante da presença da vibração da flecha nietzschiana ( últimos escritos). Passemos então ao manejo da ferramenta-Nietzsche, por Foucault.

\section{Visão geral da flecha nietzschiana nos escritos de Foucault}

Só é possível estar calado e permanecer tranqüilo senão quando se têm flechas no arco ( NIETZSCHE, Da Guerra e dos Guerreiros, 1994, p. 47)

A flecha de Nietzsche lançada no século XIX encontrou, no século $\mathrm{XX}$, as mãos de Foucault para que se mantivesse vibrando na sua mais alta qualidade intempestiva. Ela também possibilitou a Foucault ir se transformando em arqueiro, trazendo em seus escritos um vasto horizonte de problematizações, bem como se metamorfoseando num artesão de flechas quando inventa conceitos, peridiocidades, narrativas que desgovernam as já existentes, realizando, através de intervenções pontuais, o que Nietzsche nomeou de "transvaloração do pensamento". Ou seja, Foucault nos ofereceu novas ferramentas de análise do presente para que o caminho aberto por Nietzsche em torno de sua proposta de transvaloração dos valores pudesse ser percorrido por nós, através de nossas práticas diárias de intervenção no socius e amplificou também o gesto de Nietzsche quando nos convida, em seus últimos escritos, a realizarmos práticas conosco, a "pesquisar quais são as formas e as modalidades da relação consigo através das quais o individuo se constitui e se reconhece como sujeito".(FOUCAULT, 1984, p.11).

Importante assinalar que Foucault literalmente acolheu flechaNietzsche, pois foi um dos responsáveis pela direção da edição francesa das obras completas do filósofo, junto a Deleuze, em 1966, num empreendimento que anteriormente havia ocorrido na Itália, com Colli e Montinari, a fim de retirar as deformações que a obra sofreu em função do endereçamento que foi dada a ela, pela irmã de Nietzsche, e que acabou criando um Nietzsche anti-nietzschiano, posto que anti-semita. (FOUCAULT, 2008a, p. 36). Por isso, Foucault comenta em entrevista a revista Le Figaro littéraire, em 1966, que objetivo dessa edição era 
reconstruir, na medida do possível, os textos conforme a perspectiva de Nietzsche (FOUCAULT, 2008a, p. 31).

Os critérios utilizados na edição, como comenta Foucault, era o de mostrar o processo do pensamento de Nietzsche, os múltiplos planos que o constituem, isto é, "como retoma e transforma uma ideia anterior, como renuncia a utilizar agora uma ideia que retomará mais tarde, como se prepara ou se esboça uma idéia futura, em que momento se forma ou qual grande conceito nietzschiano" (FOUCAULT, 2008a, p.38). Dessa maneira, ele e Deleuze fizeram questão de discorrer acerca das novidades de seu pensamento, o modo de expressá-lo etc. bem como deixam claro que o desejo de ambos, era que esses escritos inéditos fossem o "novo dia", "o retorno a Nietzsche" ou ainda "o estado inacabado do livro do advir" (2008a, p.39).

Convém salientar que, em 1962, Deleuze publicara um livro sobre Nietzsche, que Foucault leu e gostou, mas a difusão do pensamento nietzschiano na França, de acordo com inúmeros relatos, se deve a Foucault (ERIBON, 1990), sendo visto, por muitos, como o responsável pelo Nietzsche da juventude francesa dos anos 70, em função da presença de Nietzsche em seus escritos dos anos 60, mas, sobretudo, em função do seu famoso artigo "Nietzsche, Freud e Marx" derivado de sua fala no Colóquio de Royaumont em 1964. Como assinala Marton (1985), Foucault, ao aproximar "Nietzsche, Marx, Freud", mostrando que, no séc XIX, eles teriam inaugurado uma nova hermenêutica, gerou grande impacto, pois "não se tratava de examinar esses pensadores para contrapor suas ideias ou de recorrer a um deles para demolir o outro, mas de relacioná-los justamente porque, em vez de multiplicarem os signos do mundo ocidental, criaram uma nova possibilidade de interpretá-los". (MARTON, 1985, p.8)

Tanto que esse artigo reverberou no Colóquio sobre Nietzsche, em Ceresy, no ano de 1972, em que vários pensadores alemães e franceses, dentre eles Deleuze, se remetiam ao artigo de Foucault e a perplexidade dos alemães, na figura de Lowith, diante da explosão Nietzsche na França, posto que na Alemanha ele já não produzia interesse ${ }^{11}$, mas também falou da tríade Freud- Marx- Nietzsche e de Fink ${ }^{12}$ que também não se maravilha com Nietzsche, afirmando que sua obra literária teve uma força pontual no inicio do século, mas que hoje não influenciava mais os escritores de talento.

\footnotetext{
${ }^{11}$ Palavras de Lowith: Amavelmente convidado para este colóquio, hesitei, de inicio, em participar dele, porque, baseando-me na situação filosófica alemã, não podia imaginar que por dez dias inteiros se pudesse, ainda hoje, falar e discutir a respeito de Nietzsche. E fiquei realmente estupefato com que houvesse ainda, ou novamente, na França, um tão grande interesse por Nietzsche, mesmo que mesclado a Marx e Freud. (MARTON, 1985, p.140).

${ }^{12}$ Palavras de Fink: “A fascinação que exerceu sua obra literária, principalmente no inicio do século; o encanto com que ela entreteve espíritos de grande classe intelectual e uma juventude capaz de entusiasmo - tudo isso pertence ao passado" (MARTON, 1985, p.169).
} 
Podemos então dizer que embora Deleuze tenha escrito um livro sobre Nietzsche, já em 1962, a sua difusão só se tornou possível após a força que Foucault deu a Nietzsche, bem como o modo pelo qual direcionou sua flecha, pois, a partir daí, Nietzsche, transformado em caixa de ferramentas, possibilitou diversos usos para ele e pode se manter como flecha que atravessa outros pensadores e produz novas imagens, problematizações e novas flechas. E, além disso, mesmo Deleuze estando, junto a Foucault, na empreitada de "devolver a Nietzsche a sua verdadeira cara", dirá, ao fazer um "retrato de Foucault" que se "Nietzsche dizia que um pensador sempre atira uma flecha, como no vazio, e que um outro pensador a recolhe, para enviá-la em outra direção, esse seria o caso de Foucault". (DELEUZE, 1992, p.146-147).

\section{A flecha-Nietzsche cravada nos escritos arqueológicos de Foucault}

Munido, então, da flecha nietzschiana, Foucault, através de seus escritos dos anos 60, mostrará porque define Nietzsche como um filósofo arqueólogo, tal como comenta em entrevista concedida a M.G Foy, em 1966: "Nietzsche (...) desempenha de alguma forma o papel de arqueólogo", pois, para ele, "o filósofo era aquele que podia diagnosticar o estado do pensamento (...) que estuda o espaço no qual se desdobra o pensamento, assim como as condições desse pensamento, seu modo de constituição". (FOUCAULT, 2008a, p.35)

E, talvez por isso, um ano depois, em 1967, em outra entrevista, declara-se "filósofo" (coisa rara de acontecer) por reconhecer-se no trabalho de quem "busca diagnosticar, realizar um diagnóstico do presente", o que "desde Nietzsche caracteriza a filosofia contemporânea". E conclui:

Falei- lhes de um desaparecimento das filosofias e não de um desaparecimento do filósofo. Creio que existe certo tipo de atividades 'filosóficas' em domínios determinados que consiste em geral em diagnosticar o presente de uma cultura: é a verdadeira função que podem ter hoje os indivíduos a que chamamos filósofos ( FOUCAULT, 1994, p. 601)

Os escritos desse período são: História da Loucura na época clássica (1961), O Nascimento da Clínica: uma arqueologia do olhar médico (1963), As palavras e as coisas: uma arqueologia das ciências humanas (1966), Arqueologia do saber, publicado em 1969, o Colóquio Nietzsche, Freud e Marx (1964), que já assinalamos, e a aula inaugural no Collège de France, intitulada "A Ordem do Discurso", que, embora tenha ocorrido nos anos de 70, retoma as discussões desses livros. Nesses escritos problematizará os discursos, as práticas e os saberes que emergem na modernidade a partir da descoberta do homem como objeto das novas ciências, buscando, assim, 
interrogar as formas de racionalidade que o sujeito humano aplicava a si mesmo.

Nesses escritos há também a criação de uma periodicidade inovadora no que tange a maneira de situar a análise da emergência de temas que modificam o cenário dos séculos, denunciando descontinuidades ali mesmo onde, até então, parecia haver evolução das ciências em direção ao homem, bem como a ênfase em espaços que não eram alvo de historização. Tal procedimento descontinuísta se tornou possível através da submissão dos discursos à historicidade dos mesmos. Tal procedimento assinalava que a flecha do tempo não percorre uma direção linear. Ou seja, o cenário histórico não é linear e progressivo, mas emerge de relações de força, implicando em rupturas e invenções.

Em última instância, inventa-se, na modernidade, o homem, não se passa a conhecê-lo e nem efetivamente se conhece ele, mas ele é inventado através de saberes, de modo que, em si mesmo, ele não existe. Porque o homem, transformado em objeto do saber, precisou ser adequado ao regime das demais ciências, mas quanto mais se investigava a respeito desse objeto, mas ele escapava do regime de previsibilidade e objetividade, impossibilitando que fosse localizado numa ordem natural, o que não impediu que as ciências do homem, para vencer essa tensão constituinte que cerca seu objeto, se mantivessem presas a uma crença inabalável da natureza humana, passando a orientar seus procedimentos através de atitudes corretivas e adaptadoras para, assim, alcançar um suposto estado de normalidade que resolveria essa tensão, sendo que tal estado apaziguador também partia de uma invenção dos saberes e não de um dado inerente ao "objeto estudado".

Deleuze (2005) sugere que, para Foucault, o saber é constituído por uma combinação do ver e do falar. Ou seja, cada época histórica diz tudo o que pode dizer em função de suas condições de enunciado, assim como vê e faz ver tudo o que pode em função de seus campos de visibilidade. O saber constitui, portanto, os limites do que pode ser visto e do que pode ser dito em cada época, por isso, precisamos colocá-los em análise, problematizálos.

Importante assinalar que o que Foucault nomeia como problematização é o que "unifica todos os seus trabalhos desde a História da Loucura", e deixa claro que não pode ser remetida como ele mesmo diz, "a representação de um objeto preexistente, nem também criação pelo discurso de um objeto que não existe". Mas estão ligadas, ao "conjunto de práticas discursivas ou não discursivas que faz entrar algo no jogo do verdadeiro e do falso e o constitui como objeto para o pensamento (seja sob a forma da reflexão moral, do conhecimento científico, da análise política, etc.)" (FOUCAULT, 2012, p.236).

Por isso, em 1984, Foucault, ao fazer a retrospectiva de suas obras, dirá que seu objetivo era "interrogar como ocorre que o sujeito humano se 
torne, ele próprio, um objeto de saber possível, através de que formas de racionalidade, de que condições históricas e a que preço?" (FOUCAULT, 2008a, p.319). Essa interrogação se estendia para a temática da loucura da seguinte maneira: "a que preço o sujeito pode dizer a verdade sobre si mesmo e a que preço quando ele mesmo é louco? Como se pode dizer a verdade sobre o sujeito doente?" (FOUCAULT, 2008a, p.319). E, o mesmo em relação ao sujeito falante, ao que trabalha, ao que vive, o que implicou em analisar o nascimento da gramática, da gramática geral, da história natural e da economia, tal como aparece em As palavras e as coisas.

Foucault quis deixar claro que, em sua arqueologia, "o buraco é mais embaixo", isto é, que tal como Nietzsche, "não estuda as ideias em sua evolução supostamente natural, mas "vê debaixo das ideias como puderam surgir tais e tais objetos possíveis de conhecimento" (2008a, p.319-320). E, através desse procedimento, mostrar que não há um ato fundador e primeiro do sujeito racionalista. Essa abolição do ato fundador do sujeito é o legado deixado por Nietzsche. Por isso, Foucault, em outro momento, dirá que "se trata de furar toda massa do discurso acumulado sob os nossos pés" e, ao se descobrir, quando questionamos as palavras que ressoam ainda em nossos ouvidos e percebemos que elas se confundem com as que ainda precisamos sustentar, "ai então o arqueólogo, como filósofo nietzschiano, é forçado a operar a golpes de martelo" (FOUCAULT, 2008a, p.76). ${ }^{13}$

A flecha de Nietzsche percorre todos os escritos arqueológicos de forma pungente dando vibratibilidade às discussões, propostas por Foucault e exteriores a filosofia: loucura, medicina, linguagem, literatura, história, ciências humanas, mas que são, também, colocadas a ela, problematizando, de forma indireta, o lugar ocupado pela metafísica no reino das ideias modernas que se corporificam, também, nos saberes, criando, assim, tal como Nietzsche, a necessidade de se inventar uma outra concepção para a história. Dito de outro modo, Foucault, ao interrogar a história do saber, interroga também, de forma indireta, a história da razão e demonstra, através da arqueologia, as formas de racionalidade que emergem no século XIX.

Para efeito de visualização da presença de Nietzsche nesse momento, podemos exemplificar alguns pontos.

\section{História da Loucura}

Em História da Loucura, há muitas referências a Nietzsche, não temos a intenção de apresentá-las nesse artigo, mas podemos dizer que Foucault, já no prefácio do livro, deixa claro ao leitor que foi escrito "sob o sol da grande pesquisa nietzschiana". Por um lado esse sol pode se referir

\footnotetext{
${ }^{13}$ Entrevista dada em 1967, a Raymond Bellourt, intitulada "Sobre as maneiras de escrever a história".
}

Ressonâncias de Nietzsche em Foucault: o encontro criativo da flecha do pensamento - Aline Ribeiro Nascimento 
ao momento em que Foucault leu pela primeira vez Nietzsche, em 1953, nas praias italianas durante as férias, no verão de 1953; lia "As Considerações Intempestivas", como assinala Eribon (1990, p.66), apoiado pela lembrança de Veyne. Curiosamente, numa entrevista dada por Foucault, a G. Raulet, em 1983, dirá que a História da Loucura "foi escrita entre 1955-1960" e que "não era nem freudiano, nem marxista, nem estruturalista, mas que havia lido Nietzsche em 1953, numa perspectiva de interrogação da história do saber, a história da razão, de como é possível fazer uma história da racionalidade" (FOUCAULT, 2008a, p. 312). E também não podemos deixar de mencionar, uma avaliação feita sabiamente por Michel Serres, comentado por Eribon, quando diz que esse livro de Foucault, "é para a tragédia clássica (e mais genericamente para a cultura clássica) o que a trajetória nietzschiana é para a tragédia e a cultura helênicas: evidencia os dionisismos latentes sob a luz apolínea" (ERIBON, 1990, p.125).

\section{Nascimento da Clínica}

No Nascimento da Clínica, embora, ao longo do livro, não haja citações de obras de Nietzsche, no seu prefácio Foucault dirá, apoiando-se em Nietzsche, que estamos historicamente consagrados à história e essa à paciente construção dos discursos sobre discursos, tendo por tarefa saber ouvir o que já foi dito, de modo que se faz necessário, tal como Nietzsche, filólogo, comprova, a necessidade de submeter uma crítica à linguagem (1977, prefácio, p. XIV-XV). Essa afirmação ajudará Foucault a formular uma articulação entre olhar e linguagem no horizonte do conhecimento médico, possibilitando que compreendêssemos a existência de uma ruptura entre a medicina clássica e a moderna justamente na mudança operada pelas formas dadas às visibilidades e o que é posto para funcionar na maneira de dizê-las. Bem como analisar a forma discursiva em seu sentido amplo, englobando toda uma série de reflexões políticas, programas de reformas, medidas legislativas, regulamentos, considerações morais etc.

Quando visitamos a obra de Nietzsche, filólogo, percebemos que o que ele comprova é que devemos suspeitar da maneira como até então lidamos com a linguagem e a história, isto é, os enunciados que designamos verdadeiros estão carregados de valores, sendo necessário submetê-los ao valor das valorações, isto é, não podemos naturalizar os discursos, precisamos indagar o que eles põe para funcionar na história, valem para quê? Não importa quem fala, mas o momento em que fala e o lugar social que este que fala ocupa, bem como o que põe para funcionar. $\mathrm{E}$ ainda, que o que essas palavras enunciam vai sendo modificado ao longo da história, portanto, não se trata nunca do mesmo sentido para as palavras e nem os mesmos problemas. Todas as séries discursivas são fabricadas em momentos diferentes, com sentidos diferentes, mas, ao serem sistematizadas, nos dão a ilusão de continuidade histórica. Para demonstrar 
essa análise Nietzsche, na Genealogia da Moral, nos conduzirá às diversas emergências de sentido dada ao bom e ao mal, através de um rigoroso trabalho filológico em torno dessas palavras e de outras derivadas delas e como, cada ponto de emergência estava ligado a dinâmica de forças de uma época e a produção de modos de existência correlatos, questões que não são diretamente trabalhadas por Foucault nesse momento.

Curioso observar ainda que, nessa obra, Nietzsche, numa nota de rodapé (1998, p. 45), expressa um desejo: de que alguma faculdade de filosofia, impulsionada pelas discussões dessa obra, tome para si o mérito de promover os estudos histórico-morais propondo como questão: "que indicações fornece a ciência da linguagem, em especial a pesquisa etimológica, para a história dos conceitos morais?". Questionamento que, segundo ele, deveria merecer atenção de filólogos, historiadores e estudiosos de filosofia, sendo, importante também "fazer com que fisiólogos e médicos se interessassem por esse problema (o do valor das valorações até agora existentes)", encontrando, nos filósofos, os mediadores desse processo, "após terem conseguido transformar a relação entre filosofia, fisiologia e medicina, originalmente tão seca e desconfiada". E Foucault, nesse livro, não faz exatamente isso? Um diálogo com os fisiólogos e os médicos a partir de uma outra maneira de olhar a história problematizando o valor atribuído a suas funções,os tipos de indivíduos fabricados a partir delas e as mudanças nos enunciados discursivos que instituem novas tábuas de valores?

\section{As palavras e as coisas}

Em As Palavras e as coisas, se debruçará de forma contundente sobre o tema da linguagem e dirá que ela só entrou mesmo no campo do pensamento no final do século XIX, mas que fora Nietzsche "o primeiro a aproximar a tarefa filosófica de uma reflexão radical sobre a linguagem", abrindo, assim, um espaço filológico-filosófico para nós (FOUCAULT, 1999, p. 420). Quando adentramos no livro observamos que a flechaNietzsche estará presente tanto em relação à temática geral do livro: $a$ linguagem, quanto à outra, mais específica: o sono antropológico. Em relação ao primeiro tópico, trata-se, a partir de Nietzsche, fundamentalmente, de responder à questão: quem fala?, discussão que já estava presente no Nascimento da Clínica. Na resposta a essa pergunta "quem fala?", Nietzsche não vai mais encontrar um sujeito, mas um jogo de forças e, através de seu modo de escrever e dizer essas forças, acaba nos levando a pensar que o espaço onde a linguagem pode ser pensável é na literatura, tal como autores qual Blanchot, Bataille e Klossovski, leitoresliteratos de Nietzsche, sugerem e, nessa obra, são acolhidos por Foucault a fim de pensar na existência desse espaço singular e recente, a literatura, que funcionaria como uma espécie de dobra da episteme moderna. 
Quanto ao segundo tópico, Foucault nos levará a interrogar como podemos despertar do sono antropológico. Isso significa, num primeiro momento, que o início do despertar se faz quando problematizamos os efeitos de controle que criamos para viver em sociedade, através das leis que fundam uma cultura, dos códigos que nos subordinam a ela através da linguagem, da economia, dos modos de perceber as coisas, de construir práticas e discursos que encontram, no homem, a justificativa para funcionarem de uma determinada maneira, como se a história da humanidade caminhasse em direção ao progresso do espírito, às luzes, a racionalidade absoluta que salva o homem de suas ilusões e prometem uma salvação na suposta humanidade do homem, na sua consciência ou na sua experiência de finitude.

Assim, todos os discursos fundados na modernidade nos mantêm como assinala Lebrun (2006, p.344), "num novo sono dogmático que só acabará quando se tiver a coragem de reconhecer que o homem não passa de um nome de um dispositivo da episteme moderna". Dirá Foucault que só despertaremos do sono antropológico, dogmático, "quando se tiver suspendido (...) além do psicologismo e do historicismo, todas as formas concretas do preconceito antropológico" (FOUCAULT,1999, p. 472). Só dessa maneira, será possível "interrogar os limites do pensamento" e "foi Nietzsche quem deu sinal disso" (FOUCAULT, 1999, p. 472). Logo, Foucault, animado por Nietzsche, nos permite despedaçar os ídolos, mostrando as forças transgressoras que emergiam na mesma época em que se erigia esse novo ídolo o homem, e uma nova moral: a humanista.Por isso, embora o pensamento moderno se construa sobre essas bases, no mesmo movimento dessa construção emergem forças transgressoras oriundas da literatura, qual Sade, Mallarmé etc. como uma outra forma de utilizar a linguagem e que nessa nova abordagem mostram "como o jogo próprio e autônomo da linguagem vem se alojar precisamente onde o homem acaba de desaparecer", tal como Foucault dirá numa entrevista em 1966 (FOUCAULT, 2011, p.155).

Além disso, os saberes modernos, enquanto saberes antropológicos, passam a ser considerados sob a luz do niilismo nietzschiano a partir do anúncio da morte de Deus como momento ápice da história moderna na qual a relatividade dos valores tecidos, nesse momento histórico, deveria ser radicalizada junto a uma crítica do humanismo burguês (as ideias modernas). Isso porque, os saberes modernos, perpetuadores, no campo social, das ideias modernas, da racionalidade pura, procuraram ocupar, através de um discurso humanista, os lugares antes fundados no absoluto, porém mantinham-se cativos, ainda, de sua forma de valorar, pois instauraram um novo tribunal sobre a vida e delimitaram as formas do pensamento a partir desse de um novo juízo moral: o humanista e de um objeto ambíguo: o homem, "objeto a ser descrito e analisado", por um lado, e por outro, "considerado como aquilo que justifica toda ciência". Nessa 
ambiguidade que emergem todas as ciências do homem que, por sua vez, sustentam o ideal humanista e iluminista.

Dai, Foucault, apoiado na flecha-Nietzsche, retoma sua fala, quando diz: "Temo que jamais nos desembaracemos de Deus porque cremos ainda na gramática", para poder afirmar que "Deus é talvez menos um além do saber que um certo aquém de nossas frases; e se o homem ocidental é inseparável dele, não é por uma propensão invencível a transpor as fronteiras da experiência, mas porque sua linguagem o fomenta sem cessar na sombra de suas leis" (FOUCAULT, 1999, p.413).

\section{Arqueologia do saber}

No arqueologia do saber, Foucault menciona Nietzsche já na introdução para mostrar que o olhar do arqueólogo, assim como o do genealogista não visa um estado de coisas constituído, mas interroga exatamente aquilo que está sendo constituído, partindo do mundo em variação e problematizando exatamente aquele lugar que privilegia a paragem dos processos. Não tenta fixar o tempo, substituindo o fluxo dos acontecimentos por continuidades. Por isso, Foucault pensa que através das formações discursivas seria possível entrarmos em contato com esse campo de variação, com a "materialização" dessas forças em luta. O que os discursos dizem? Como dizem? Por que dizem? Eis as perguntas arqueológicas que visam mostrar como os discursos articulam o que pensamos, dizemos e fazemos, num dado período e como, além disso, os acontecimentos históricos nos fazem ser o que somos e, ao mesmo tempo, possibilitam experimentarmos outros modos de ser. Por esses motivos, em 1967, numa entrevista intitulada "Sobre as maneiras de escrever a história", Foucault dirá que é necessário "furar toda massa do discurso acumulado sob os nossos pés". Para tanto, "o arqueólogo, como o filósofo nietzschiano, é forçado a operar a golpes de martelo" (2005, p.76), associando ainda sua arqueologia à genealogia.

Dessa maneira, a arqueologia poderia ser pensada como um outro nome dado por Foucault para a análise histórica, isto é, que não rejeita a história, mas "distingue nela descontinuidades, pausas, que não são universais, mas locais' (BLANCHOT, 2011, p. 123). No entanto, ao priorizar a descontinuidade, rejeita, num mesmo movimento, a relação entre história contínua e consciência, tal como aquilo que Nietzsche denunciava como doença da modernidade: o sentido histórico na Segunda Consideração Intempestiva. Afinal, a partir de Nietzsche, Foucault pode perceber que o continuísmo presente na história tradicional funciona como a suposta consciência de um sujeito que a anima e que tem clareza absoluta de sua história a fim de justificar a primazia da razão sobre os processos, de modo a fazer "da consciência humana o tema originário de qualquer devir e de 
qualquer prática", como Foucault dirá numa entrevista realizada, em 1969, para explicar o seu livro (2008a, p. 147).

Além disso, ao longo dos trabalhos dessa fase arqueológica, somos levados a lembrar da imagem do "filósofo toupeira" apresentado no prólogo do livro Aurora, de Nietzsche, definido como aquele cujo trabalho se assemelhava ao que Nietzsche fazia naquele escrito que era o de cavar mais fundo, descer às profundezas, escavar para colher e recolher o que está em baixo, aquilo que ninguém vê, que é mantido inconsciente, adormecido, realizando, portanto, um movimento oposto ao comumente feito pela tradição filosófica ao privilegiar a consciência como lugar da verdade e a racionalização como forma privilegiada da consciência.(NIETZSCHE, 2004, Prólogo 1, p. 9). E, poderíamos dizer que, nessa escavação, tanto Nietzsche, quanto Foucault encontraram passagens secretas que lhes traziam de volta para a exterioridade, onde fecundavam a terra, possibilitando que novas sementes brotassem dela a partir do cuidado zeloso com a potência que brota quando se confere historicidade aos valores que se aderem ao pensamento encontrado a partir dessa escavação nas profundezas e, assim, promovendo novas direções para a história das práticas e dos sujeitos.

$\mathrm{E}$, se nesse momento Foucault se deteve mais na dimensão discursiva, isso se deu porque percebeu que "o discurso, como se sabe, tem o poder de deter a flecha já lançada em um recuo do tempo que é seu espaço próprio" (FOUCAULT, 2006a, p. 47). Porém, o trajeto da flecha dos saberes acabou conduzindo Foucault a dimensão do poder no qual as forças que lançam as flechas para lugares variados salta aos nossos olhos e nos oferece tudo que aparece a partir de nossas práticas cotidianas. Adentremos nessa dimensão mais intensiva das flechas, dos traços-flechas, portadores de forças.

\section{A flecha nietzschiana vibrando na experimentação do conceito de genealogia por Foucault ou quando Foucault corporifica-se em arqueiro}

Vejam como está tenso o meu arco!

O mais forte é aquele que logrou essa tensão - -:

Mas, agora, cuidado! Perigosa é a seta,

Como nenhuma outra, - fora daqui! Para o bem de vocês!...

(NIETZSCHE, Do alto dos montes, 1992b, p. 203)

Nos escritos dos anos 70 observamos Foucault ousando mais em relação ao uso da flecha-Nietzsche, ou melhor, aqui Nietzsche efetivamente se apresenta como a flecha que corta esses escritos sem precisar ser citado no corpo do texto, ou mesmo em notas de pé de página, a não ser em um artigo ou em uma conferência que antecedem os escritos desse período. No entanto, sua força estará ligada ao conceito de genealogia que se torna central nos desdobramentos do pensamento de Foucault, mas com uma nova direção. 
Esse uso mais instrumental da "flecha-Nietzsche", o mais intensivo aparece, então, materializado no modo como Foucault adentra no universo das práticas sociais caracterizado pela emergência, em seus escritos da noção de dispositivo ${ }^{14}$, que será o eixo de análise que atrelará a questão da constituição dos saberes aos modos de exercício de poder. Como assinala Deleuze (2005), os dispositivos atuam como flechas, penetrando incessantemente nas coisas e nas palavras.Dessa forma, acabou dando maior concretude à formulação nietzschiana acerca do caminho a ser percorrido para que haja possibilidade de transvaloração dos valores: o caminho genealógico. Ao mesmo tempo, formula enunciados nietzschianos ${ }^{15}$, isto é, Nietzsche não precisava mais aparecer nas obras, Foucault já era flecha, no entanto, mantinha o traço da flecha-Nietzsche vibrando nele, como é o caso, por exemplo, do primeiro volume da História da sexualidade, no qual Nietzsche não é mencionado, mas, curiosamente, o subtítulo Vontade de saber é uma homenagem a Nietzsche, como o próprio Foucault afirma numa entrevista com G. Raulet, em 1983 (2008a, p.320).

Nessa nova direção de análise, Foucault começa a se interrogar acerca das práticas sociais modernas e das forças em jogo na emergência dessas práticas, bem como as verdades que põe para funcionar e sua relação de imanência junto às instituições sociais, marcando, assim, "a passagem do estudo das práticas discursivas para as práticas sociais que constituem seu pano de fundo", como comenta Blanchot (2011, p.133). Nesses novos estudos os temas da criminalidade e delinquência, bem como o da sexualidade assumirão um lugar privilegiado nas discussões, funcionando como analisadores dos efeitos do regime de verdade da sociedade. Isso significa que, se há uma política geral de verdade, a sociedade acolhe determinados discursos e enunciados como verdadeiros, cria mecanismos e instâncias para que essa verdade vingue, fornece um estatuto privilegiado para aqueles que têm como encargo dizer o que funciona como verdadeiro e, ao mesmo tempo, cria, como correlato inevitável, um campo de exclusão (os discursos falsos, os enunciados falsos) bem como aqueles que podem corrompê-la: os que equivocam sua lógica.

\footnotetext{
${ }^{14}$ Nas palavras de Foucault: Através desse termo tento demarcar, em primeiro lugar, um conjunto decididamente heterogêneo, que engloba discursos, instituições, organizações arquitetônicas, decisões regulamentares, leis, medidas administrativas, enunciados científicos, proposições filosóficas, morais, filantrópicas. Em suma, o dito e o não dito são os elementos do dispositivo. O dispositivo é a rede que se pode estabelecer entre esses elementos" (1979, p244)

${ }^{15}$ Alusão a Deleuze, quando diz: Quem é hoje em dia um nietzschiano? Será aquele que prepara um trabalho sobre Nietzsche? É possível. Ou bem será aquele que, voluntária e involuntariamente, produz enunciados particularmente nietzschianos no decorrer de uma ação, de uma paixão, de uma experiência? (...) Talvez os dois casos não se excluam. Talvez se possa escrever sobre Nietzsche e depois produzir, no decorrer da experiência, enunciados nietzschianos. (1985, p. 56),
}

Ressonâncias de Nietzsche em Foucault: o encontro criativo da flecha do pensamento - Aline Ribeiro Nascimento 
Ora, o combate em torno do estatuto da verdade é a força que move os escritos nietzschianos, mas o endereçamento político-econômico não é o norte das análises de Nietzsche, mas sim, o modo pelo qual esse estatuto retira a potência do pensamento porque o endereça para o niilismo. De todo modo, o conjunto de regras que estabelece estará ligado a efeitos de poder específicos amplamente trabalhados por Nietzsche. Por isso, Foucault deixa claro que por verdade, não quer dizer: "o conjunto das coisas verdadeiras a descobrir ou a fazer aceitar". Mas entendê-la, como o "conjunto das regras segundo as quais se distingue o verdadeiro do falso e se atribui ao verdadeiro efeitos específicos de poder" (1979, p.13).

$\mathrm{Se}$ submetermos os escritos anteriores a essas novas problematizações, poderíamos dizer que a análise dos saberes levará em conta as condições de possibilidade de sua emergência junto a relações de poder e verdade. Por exemplo, o saber psiquiátrico, ao se constituir em cima de práticas que fazem emergir o louco através de discursos sobre a loucura, nos permite compreender, de forma precisa, os efeitos em conjuntos do saber, do poder e da verdade na sociedade tendo em vista que a prática "psi" está ligada a uma série de instituições, de exigências econômicas imediatas e de urgências políticas de regulamentações sociais que transformam o louco naquele que equivoca a razão, sendo danoso à sociedade e, por isso, precisa de tratamento e internação pelos experts na loucura. Ao mesmo tempo em que essa análise nos permite ir vendo a constituição do sujeito na trama histórica, como uma identidade vazia, que, no entanto, é inventada por inúmeros preenchimentos provindos de diversas instâncias a fim de torná-la real.

Mas, para chegar alcançar esse novo projeto analítico, Foucault, incluiu, em suas discussões, um dispositivo político fornecido pela genealogia, complementando, assim, as discussões anteriores acerca da arqueologia do saber. A genealogia do poder, termo que será usado por Foucault, aparecerá como aquilo que introduz, em suas pesquisas, análises históricas da questão do poder como instrumento de análise para explicar a produção dos saberes, encontrando, no corpo, o espaço no qual as relações de poder se formalizam em saber, na sociedade ocidental.

Assim, as discussões anteriores ligadas à proliferação de noções antropológicas e a crítica ao humanismo correlata a ela são colocadas sobre novas bases: o corpo é o fio condutor das análises, ligado, por sua vez, a conceitos nietzschianos como vontade (de poder e de verdade) atrelados à genealogia. O conceito de vontade de verdade permitirá a Foucault problematizar as teorias do conhecimento, o de genealogia a criar um novo olhar para a escrita e escuta da história, aumentando o alcance das discussões em torno da descontinuidade a partir da ênfase dada ao conceito de acontecimento e, em relação ao conceito de vontade de poder, encontrará um campo fértil para realizar uma história do poder desatrelada do Estado, afastando-se, assim, das discussões marxistas. 
Podemos observar quatro momentos interessantes no que tange ao uso de Nietzsche por Foucault em seus escritos e ditos. Em 1971 escreve, como que para fazer uma passagem da "fase arqueológica" para a "genealógica" o comentado artigo: "Nietzsche genealogia e história" e, em 1973, em uma de suas visitas ao Brasil, à primeira aula das cinco conferências que dá sob o título de "A Verdades e as formas jurídicas", há referências diretas a Nietzsche, mas, os livros propriamente ditos, posteriores, não fazem mais menção à Nietzsche, a saber: Vigiar e Punir (1975) e História da Sexualidade: vontade de saber (1976), o uso dos prazeres (1984) e o cuidado de si (1984).

Não temos o propósito de analisar detidamente o artigo de 1971, apenas pontuaremos que Foucault apresenta ao leitor pontos importantes da Genealogia da Moral e da famosa Segunda Consideração Intempestiva que tanto lhe inspirou na outra fase. Isso porque a Genealogia da Moral é um acabamento melhor da Segunda Consideração Intempestiva, pois reflete um momento de maturidade do pensamento de Nietzsche no qual conceitos importantes de sua obra já haviam sido formulados como: vontade de potência, eterno retorno, grande saúde, grande política etc.

A partir desse escrito, Foucault formulará sua proposta genealógica, permitindo-o distinguir "os acontecimentos, diferenciar as redes e os níveis a que pertencem e reconstituir os fios que os ligam e que fazem com que se engendrem", em suma, "fornece uma análise da relação de poder, não da relação de sentido", como afirma na entrevista de 1977. (1979, p. 5). Quanto se prioriza o acaso da luta não se está dizendo que a história é incoerente, mas que é inteligível a partir das lutas, das estratégias e das táticas. Essa proposta se efetiva nos livros Vigiar e Punir e História da Sexualidade I: a vontade de saber.

Vigiar e Punir foi o primeiro livro dessa nova fase de suas pesquisas na qual a palavra genealogia aparecerá pela primeira vez, num livro seu e o que permitirá, por exemplo, aos comentaristas Dreyfus e Rabinow (1995, p. XXI) afirmarem que ele "usa genealogia de Nietzsche como ponto de partida para um novo método de análise que lhe permita tematizar a relação entre verdade, teoria e valores e as instituições e práticas sociais nas quais elas emergem". Esse novo método de análise poderia ser chamado de genealogia do indivíduo moderno: a analítica interpretativa do poder, da verdade e do corpo, como também sugerem os comentaristas (1995, p.113). O termo é tão forte que até a sua fase final será remetida a Nietzsche, mas como genealogia do sujeito.

Tanto nesse livro, quanto na História da Sexualidade I, fará questão de estudar o poder, os mecanismos do poder, afirmando que eles não foram estudados, mas, sim, as pessoas e as instituições que detinham o poder, como se elas fossem fontes do poder. E, ao estudar os mecanismos do poder, observou que ele não é a fonte ou origem de algo, como por exemplo, dos discursos, mas algo que se opera através dos discursos, entendendo, 
assim, os discursos como dispositivo estratégico das relações de poder, como dirá em uma entrevista com estudantes ocorrida em 1978 que recebeu o título de "Diálogo sobre o Poder" (FOUCAULT, 2006b ,p. 253).

Dirá também que o poder não pode ser reduzido a questões de ordem econômica, pois ao ser colocado somente sob essa ótica não se alcança as engrenagens do poder presentes, por exemplo, no internamento psiquiátrico, na normalização mental dos indivíduos, nas instituições penais, no modo como nos relacionamos com a sexualidade etc. Ou seja, deixam-se de lado as técnicas do poder vinculadas à formação histórica das sociedades capitalistas, que, no caso do Vigiar e Punir implicam na análise minuciosa da emergência da instituição carcerária e no História da Sexualidade I a constituição do dispositivo da sexualidade. A formulação genealógica do poder interroga acerca das condições de possibilidade política que tornam possíveis a emergência de formas, como os saberes, por exemplo, acompanhando as relações de forças que sustentam essas formas, inclusive a forma-Estado.

Por isso, fará questão de separar o poder, do Estado, isto é, de pensálo como sendo originado do Estado, tendo em vista que ao ser entendido como relação de forças, não tem origem, nem finalidade, o que não significa que não possa manifestar-se no Estado ou em qualquer outra instância como o judiciário, a escola, a família, etc. Mas simplesmente porque o poder enquanto relação de forças - se expande por todo corpo social, através das práticas sociais, de técnicas, que o expande porque atingem a materialidade mais concreta dos indivíduos- o seu corpo, intervindo nele e penetrando na vida cotidiana.

Ao longo do Vigiar e Punir, Foucault vai mostrando que a construção da alma moderna é a história política dos corpos disciplinados que emerge da relação de co-pertencimento entre poder e saber: de como o poder produz saber e como o saber sustenta o poder. Se o poder produz assujeitamento, é necessário entender como as relações de sujeição podem fabricar sujeitos, quais as técnicas de coerção que põe para funcionar e como elas se sustentam. Por isso, importa a Foucault entender como se constituíram os assujeitados, isto é, analisar os procedimentos que sujeitam os corpos, dirigem os gestos, regem os comportamentos numa dada época. Essa discussão é comum tanto ao Vigiar e Punir (1975) quanto a História da Sexualidade I (1976).

Diante do que expomos até aqui, fica evidente que embora Foucault se sirva da flecha nietzschiana em seus escritos, o modo de usar essa flecha o transformou em arqueiro porque ele não se restringe a criar uma nova teoria a partir de um estudo meramente bibliográfico da obra de Nietzsche, como se Foucault pesquisasse e pensasse fechado num escritório e não criasse nada de novo. Todos os seus escritos ligam teoria à prática, ou melhor, as teorias são caixas de ferramentas para práticas, não verdades e, além disso, todos os seus conceitos nasceram de experiências diretas no 
campo de análise, na escuta das vozes infames. Por exemplo, ele só começou a escrever o Vigiar e Punir depois de ter participado, durante anos, de grupos de trabalho nos quais se refletia sobre a prisão e a luta contra as instituições penais com detentos, familiares, pessoal da vigilância, magistrados etc. como dirá, em 1980, em uma conversa com D. Trombadori. (FOUCAULT, 2010, p.295). E, se, ao longo de seu trabalho, resolveu problematizar os mecanismos de poder, essa necessidade só emergiu em função de ter encontrado, nas experiências concretas e localizadas, a possibilidade de formulação dessa questão, que, até então, se mostrava muito abstrata ou inexistente nos sistemas teóricos. Percebeu que essa questão estava em todo lugar, pois também viajava muito e participava de inúmeros debates, o que deu materialidade para compreender que o exercício do poder não se restringia ao poder de Estado, mas se exercia em outras instituições ou países e aparecia nas diversas formas de constrangimento ligadas à vida cotidiana. Dessa maneira, pôde entender que as instituições, funcionando em nome da razão e da normalidade, na realidade, exerciam poder sobre grupos de indivíduos, em relação com comportamentos, maneiras de ser, de agir ou de dizer, constituídos como anomalia, loucura, doença etc. afirmando que não fez outra coisa, ao longo de seus escritos, senão a história do poder (FOUCAULT, 2010, p.333).

Portanto, a genealogia do poder, proposta por ele, acabou fazendo com que tanto os seus conceitos, quanto os de Nietzsche ganhassem vida, pois se mostraram presentes nas práticas cotidianas, emergiam delas, por elas ou a partir delas. Por isso, dirá que, ao longo de seu trabalho, escuta os problemas lá onde emergem: o que dizem os loucos? Como é a vida em um hospital geral? Qual é o trabalho do psicólogo, do pedagogo, do juiz na instituição penal? Como reagem aos seus trabalhos? (FOUCAULT, 2010, p.335).

\section{A flecha foucaultiana se despede da flecha- Nietzsche?}

Lembremos que o último aspecto da flecha é a do "tiro espiritualizado" que significa que o "arqueiro" finalmente desaparece e se confunde com o seu próprio instrumento, pois somente quando a força se confunde com a materialidade do pensamento, a flecha se apresenta em estado puro e assim é capaz de atingir os outros porque foi produzida na osmose entre escrita e vida. Em Nietzsche, esse aspecto se faz mais visível em obras como o Zaratustra e talvez, mais precisamente, no escrito autobiográfico Ecce Homo. É o espaço da experiência que assume o primeiro plano, não sendo, portanto, nem espaço da arte, da literatura ou da filosofia, como assinala Foucault, numa entrevista em 1966, referindo-se a Nietzsche (FOUCAULT, 2006a, p.246). Aqui, a flecha encontra a sua forma de pura força, ela é experimentação e experimento para quem tem coragem de ser perfurado por ela. Assemelha-se a discussão trazida por Foucault em 
"O que é um autor?", bem como as "técnicas de si" trabalhadas no curso Hermenêutica do sujeito, onde, inclusive a imagem do arco e flecha aparece $^{16}$.

Os escritos nos quais essa "despedida" está presente são História da Sexualidade II: o uso dos prazeres e III: o cuidado de si publicados em 1984. Porém, na mesma época, Foucault deu uma entrevista na qual, ao ser perguntando se esse nesses escritos não se tratava de uma nova genealogia da moral, responde: "não fosse a solenidade do título e a marca grandiosa que Nietzsche lhe imprimiu eu diria que sim" (2006b, p.289). Lembremos que, em outro momento, numa entrevista de 1975 ele já dizia: "Se fosse pretensioso, daria como título geral ao que faço: genealogia da moral" (2006a, p. 174).

Qual a diferença entre fazer a genealogia da moral e criar uma nova genealogia da moral? Ora, vimos que o termo genealogia, nos escritos inspirados explicitamente na "Genealogia da moral" aparecem ligados as relações de poder que são tecidas nas práticas sociais. Quando Foucault concorda que está realizando uma nova genealogia da moral nesses novos escritos de 1984, nossa hipótese é que ele encontra duas genealogias presentes na obra de Nietzsche, uma ligada ao poder e outra ligada à potência, uma ligada a moral escrava e outra a moral nobre, embora, nesses livros, não fale nada a respeito disso.

O que isso significa? Ao longo, não só da Genealogia da moral, mas das obras de Nietzsche em que ele discute o que entende por vontade, como no Zaratustra, na Gaia Ciência, no Além do Bem e do Mal, no Ecce Homo, no Crepúsculo dos Idolos e em vários fragmentos póstumos, observamos que esse nome dado à vida se expressa ora como poder, ora como potência. $\mathrm{O}$ primeiro aspecto ligado a moral escrava e o segundo, ligado a moral nobre e, ambos, expressos no corpo, no modo pelo qual esse corpo lida com as relações de força presentes nele e fora dele de modo a nos possibilitar pensar numa moral sadia, regida pelos instintos de vida (nobre) e outra adoecida, regida pela negação deles (escrava). E, em outros momentos, a vontade de poder, bem como a vontade de verdade aparece como uma espécie de tonalidade da vontade de potência.

Além disso, Foucault percebia essas duas leituras para a genealogia a partir dos deslocamentos nos textos de Nietzsche entre os que "são amplamente dominados pela questão da vontade de saber e os dominados pela vontade de potência", conforme dirá numa entrevista dada em 1983 a G. Raulet. (FOUCAULT, 2005, p.322).

Como essas questões demandam uma análise mais fina, não temos o propósito de discutí-las nesse momento. Apenas podemos assinalar que a questão trazida por Nietzsche é pensar o tipo de força que é colocado em ação, o tipo de vontade atrelada a essa força, fazendo emergir uma vontade

${ }^{16}$ Cf. FOUCAULT, 2004, p.272 ( aula 10 de fevereiro de 1982- $1^{\text {a }}$ hora).

Ressonâncias de Nietzsche em Foucault: o encontro criativo da flecha do pensamento - Aline Ribeiro Nascimento 
forte, nobre ou uma vontade fraca, escrava, ou melhor, que "nobre" e "escravo" designam formas da vida ou tipos de moral e observará que a história do homem e da terra, ao serem manchadas pela fraqueza da perspectiva lançada pelo poder de contágio de forças niilistas da metafísica e do cristianismo acabou seguindo um rumo que fez da vontade de potência mero instrumento da vontade de poder, ou seja, a vida se endereça para uma a menos de vida, para ressentimentos com a vida e para formas assumidas na cultura que reforçam esse endereçamento: religião, Estado, leis etc. O que Nietzsche chamará de "triunfo dos fracos", na Genealogia da Moral.

Em outras palavras, é como se só conseguíssemos viver na dependência direta com as forças fora de nós: o Estado, a Igreja, a Justiça etc. porque não sabemos obedecer a nós mesmos, como se necessitássemos sempre de uma instância transcendente para nos governar e dizer como devemos agir, ser e pensar. Por isso, a grande maioria dos estímulos produzidos por nossa cultura enfraquecem o corpo, arruínam o corpo, como Foucault já havia alertado nas obras anteriores e Nietzsche também, desde a Segunda Consideração Intempestiva que, inclusive, foi o sol dos escritos da fase arqueológica, como assinalamos. E, a própria maneira de interpretar a vontade como aquilo que está ligada a consciência e/ou a moral, impede que percebamos que, na própria vontade humana há luta e que, essa luta, por sua vez, é alimentada pelas forças da cultura, que podem reforçar determinados arranjos de forças afetivas que levam o corpo ao adoecimento, o que Foucault nomeia como o fascismo em nós, no prefácio do Anti-Édipo de Deleuze e Guattari.

Ao longo da obra de Nietzsche fica claro que $o$ valor do mundo encontra-se na interpretação que damos, de modo que interpretar pressupõe avaliar, e essa avaliação foi feita por Foucault no transcorrer das obras anteriores. E, como as interpretações oferecidas pela metafísica, pelo cristianismo e pela modernidade são avaliações estreitas que, para se afirmarem, precisaram negar a expansão da potência da vida, a meta da análise genealógica é avaliar o valor dos valores criados nesse horizonte interpretativo a fim de colocar a vida como valor maior, a vida como avaliadora das forças, a vida que se desnuda nos modos de existência que a enfraquecem ou fortalecem, esse último item se mostra claramente presente nesses escritos de 1984. Ou seja, neles busca-se pensar: como não adoecer frente às forças da cultura? È possível encontrar, em algum ponto da nossa história, tipos humanos fortes, que não descolavam a vida dela mesma? Como pensar a vida uma obra de arte, tal como os Antigos propuseram? Como pensar a vontade de potência sobre o prisma da ética e não mais da moral, como até então nossa cultura vem fazendo?

Foucault, então, não se despede de Nietzsche , ao contrário, nesses últimos escritos, talvez estivesse mais próximo dele, pois além de Nietzsche fazer de si mesmo, o palco de onde emergiam suas questões e assim criar blocos de sensações que apareciam como pensamento-imagem para seus 
conceitos e tal procedimento não implicava num individualismo, como afirma no prólogo do segundo volume de Humano Demasiado Humano (2008, Prólogo 6, p.13), mas num exercício diário de atenção e disciplina da vontade, ele também esperava que seus experimentos pudessem ser acolhidos como uma experiência comum àqueles que são capazes de fazer com que o corpo não seja governado por um eu, mas que fazem "eus" a partir do jogo de impulsos e afetos, quando apresenta sua definição de grande razão no Zaratustra no discurso sobre os Desprezadores do corpo. Foucault acolhe esse desejo de Nietzsche ao longo de todos os seus escritos e, nesses últimos, nos convida a fazermos, em nós mesmos, essa experimentação.Tanto que, numa das últimas entrevistas dadas por Foucault, poucos meses antes de morrer, ele diz:

sou simplesmente nietzschiano e tento, dentro do possível e sobre um certo número de pontos, verificar, com a ajuda dos textos de Nietzsche - também com as teses antinietzschianas (que são igualmente nietzschianas!) -, o que é possível fazer nesse ou naquele domínio. Não busco nada além disso, mas isso eu busco bem (2006b, p.260)

Assim, tanto a flecha de Nietzsche, quanto a de Foucault, são flechas-lançamento, pois priorizam o movimento das forças. Por isso, são flechas-pensamento, pois implicam sempre na criação de problematizações, questionamentos, não havendo preocupação com respostas, afinal qualquer resposta pararia a flecha. Dessa forma, mesmo quando se está diante das forças do presente, quando a flecha é lançada em alvos precisos por ambos os autores, ela continua em movimento, pois além de produzir questionamentos em nós, em relação a nossas práticas, produz questionamentos a respeito de quem somos, do que nos tornamos e do que recusamos a ser, então, nos direciona para o futuro, pois produz abertura para novos questionamentos, o que nos permite entender a ontologia histórica do presente como uma força que também nos lança ao que ainda não somos.

Para finalizar, esperamos que com esse artigo possamos mostrar que, agora, somos nós que, atingidos pela direção da flecha foucaultiana, somos forçados a pensar e a criar nossas práticas a partir de nossas experimentações com o mundo que nos cerca. Afinal, sem que percebesse, Foucault, ao fazer da flecha nietzschiana uma caixa de ferramentas para pensar a atualidade das práticas, dos discursos ou o modo de se construir a história dessas práticas e desses discursos para diagnosticar os efeitos das mesmas no presente, continuou a tarefa nietzschiana que, conforme o próprio Foucault disse, numa entrevista em 1966, consistia em multiplicar os gestos filosóficos, isto é, a buscar filosofia em toda parte na política, nas artes, na história, na política etc. Porém, observamos que, ao se transformar em flecha, Foucault também multiplicou os seus próprios gestos, sendo 
procurado por pessoas de vários âmbitos, sobretudo ao provocar deslocamentos no campo filosófico e, em outros campos, como o da história, da psicologia, da psicanálise, da literatura, do direito, da sociologia etc., fazendo com que, inclusive, pudessem estabelecer um diálogo transdisciplinar ou ainda inspirando movimentos como o da antipsiquiatria, o da crítica à medicalização da sociedade, bem como o da judicialização.

Curiosamente, somente no século XXI é acolhido como filósofo, conforme podemos perceber nos inúmeros colóquios em sua homenagem, reproduzindo um caminho semelhante ao de Nietzsche, filósofo do século XIX que só foi acolhido como tal no final do século XX e, mesmo assim, somente está sendo estudado, com afinco, agora. Foucault, então, faz a flecha retornar ao mestre, mas lançando-a para o futuro, mantendo-a vibrando. O maior aprendizado da vibratibilidade da flecha talvez tenha sido alcançado a partir do exercício obsessivo de diagnosticar o presente de uma cultura, podendo, assim, acolher as suas mais variadas forças e, dessa maneira, se fazendo presente, também, em vários lugares.

\section{Referências bibliográficas}

BLANCHOT, Maurice. Michel Foucault tal como eu imagino. In: Uma voz vinda de outro lugar. Rio de Janeiro: Rocco, 2011, p. 111-159.

DELEUZE, Gilles. Pensamento nômade. In: MARTON, Scarlett (org.). Nietzsche Hoje? São Paulo: Brasiliense, 1985.

. Conversações. Rio de janeiro: Ed.34, 1992.

Foucault. São Paulo: Brasiliense, 2005.

DREYFUS, Hubert e RABINOW, Paul. Michel Foucault, uma trajetória filosófica: para além do estruturalismo e da hermenêutica. Rio de Janeiro: Forense Universitária, 1995.

ERIBON, Didier. Michel Foucault. São Paulo: Companhia das Letras, 1990. FOUCAULT, Michel. O Nascimento da Clínica: uma arqueologia do olhar médico (1963). Rio de Janeiro: Forense Universitária, 1977.

.Microfísica do Poder. Rio de Janeiro: Jorge Zahar Ed., 1979.

.História da sexualidade 2: o uso dos prazeres (1984). Rio de

Janeiro: Edições Graal, 1984.

.História da sexualidade 3: o cuidado de si (1984) Rio de janeiro:

Edições Graal, 1985.

1987.

. Vigiar e Punir: O nascimento da prisão (1975). Petrópolis: Vozes,

História da sexualidade 1: a vontade de saber (1976). Rio de

Janeiro: Edições Graal, 1988.

.História da Loucura na época clássica (1961). 3 ed. São Paulo:

Editora Perspectiva, 1993.

. A ordem do discurso ( ). São Paulo: edições Loyola, 1996.

Ressonâncias de Nietzsche em Foucault: o encontro criativo da flecha do pensamento - Aline Ribeiro Nascimento 
$\overline{(1966) .}$

As palavras e as coisas: uma arqueologia das ciências humanas

8 ed. São Paulo: Martins Fontes, 1999.

A verdade e as formas jurídicas (1973). 3 ed. Rio de Janeiro:

NAU Editora, 2002.

. A Hermenêutica do Sujeito. São Paulo: Martins Fontes, 2004.

. Ditos e Escritos III: Estética, literatura, pintura, música e cinema.

2ed, Rio de Janeiro: Forense Universitária, 2006 a.

. Ditos e Escritos IV: Estratégia, Poder-Saber. 2.ed. Rio de Janeiro:

Forense Universitária, 2006b.

- Ditos e Escritos II: Arqueologia das Ciências e história dos sistemas de pensamento. 2 ed. Rio de Janeiro: Forense Universitária, 2008 a. Arqueologia do saber (1969). 7ed. - Rio de Janeiro: Forense Universitária, 2008b. . Ditos e Escritos VI: Repensar a Política. Rio de Janeiro: Forense Universitária, 2010 .

Ditos e Escritos VII: Arte, Epistemologia, filosofia e História da

Medicina. Rio de Janeiro: Forense Universitária, 2011.

. Ditos e Escritos V: Etica, Sexualidade e Política. 3ed, Rio de Janeiro: Forense Universitária, 2012.

LEBRUN, Gérard. A filosofia e sua história: Gerard Lebrun. São Paulo: Cosac Naify, 2006.

MARTON, Scarlett (org.). Nietzsche Hoje? São Paulo: Brasiliense, 1985.

NASCIMENTO, A. R e RODRIGUES, H.C.R. Filosofia e experimentação: exercícios espirituais em Nietzsche e Foucault. Revista Fermentario, 2014 ( no prelo).

NIETZSCHE, Friedrich. Além do bem e do mal: prelúdio a uma filosofia do futuro. 2a ed., São Paulo:Companhia das Letras, 1992. . Assim falou Zaratustra: um livro para todos e para ninguém. 7a ed., Rio de Janeiro: Bertrand Brasil, 1994.

- Ecce Homo: como alguém se torna o que é. São Paulo:

Companhia das Letras, 1995.

Letras, 1998.

Genealogia da Moral: uma polêmica. São Paulo: Companhia das

Janeiro:

Crepúsculo dos Ídolos ou como filosofar com um martelo. Rio de

Relume Dumará, 2000a

Humano demasiado Humano I: um livro para espíritos livres. S.

Paulo:

Companhia das Letras, 2000b .

- A Gaia Ciência. São Paulo: Companhia das Letras, 2001.

Segunda Consideração Intempestiva: da utilidade e desvantagem

da história para a vida. Rio de Janeiro: Relume Dumará, 2003a.

Ressonâncias de Nietzsche em Foucault: o encontro criativo da flecha do pensamento - Aline Ribeiro Nascimento 
Schopenhauer educador. In: Escritos sobre educação. Rio de janeiro: Ed.

PUC-Rio; São Paulo: Loyola, 2003b, p. 138-222.

. Aurora. São Paulo: Companhia das Letras, 2004.

. Humano Demasiado humano: um livro para espíritos livres,

Volume II. São Paulo: Companhia das Letras, 2008. 